\title{
Retraction
}

\section{Retracted: A Role for PPAR $\gamma$ in the Regulation of Cytokines in Immune Cells and Cancer}

\author{
PPAR Research \\ Received 8 January 2015; Accepted 8 January 2015 \\ Copyright (C) 2015 PPAR Research. This is an open access article distributed under the Creative Commons Attribution License, \\ which permits unrestricted use, distribution, and reproduction in any medium, provided the original work is properly cited.
}

The paper titled "A Role for PPAR $\gamma$ in the Regulation of Cytokines in Immune Cells and Cancer" [1], published in PPAR Research, has been retracted as it is found to contain a substantial amount of materials from published papers. The three most original source papers are (1) X. Y. Yang, L. H. Wang, K. Mihalic, et al., "Interleukin (IL)-4 indirectly suppresses IL-2 production by human T lymphocytes via peroxisome proliferator-activated receptor $\gamma$ activated by macrophage-derived 12/15-lipoxygenase ligands," Journal of Biological Chemistry, vol. 277, no. 6, pp. 3973-3978, 2002; (2) L. Széles, D. Töröcsik, and L. Nagy, "PPAR $\gamma$ in immunity and inflammation: cell types and diseases," Biochimica et Biophysica Acta, vol. 1771, no. 8, pp. 1014-1030, 2007; (3) L. H. Wang, X. Y. Yang, X. Zhang, et al., "Transcriptional inactivation of STAT3 by PPAR $\gamma$ suppresses IL-6-responsive multiple myeloma cells," Immunity, vol. 20, no. 2, pp. 205-218, 2004.

\section{References}

[1] X. Y. Yang, L. H. Wang, and W. L. Farrar, "A role for PPAR $\gamma$ in in the regulation of cytokines in immune cells and cancer," $P P A R$ Research, vol. 2008, Article ID 961753, 12 pages, 2008. 